\title{
Bertrand Vibert, Poète, même en prose
}

\section{Ida Merello}

\section{(2) OpenEdition}

\section{Journals}

\section{Édition électronique}

URL : http://journals.openedition.org/studifrancesi/5738

DOI : ERREUR PDO dans /localdata/www-bin/Core/Core/Db/Db.class.php L.34 : SQLSTATE[HY000]

[2006] MySQL server has gone away

ISSN : 2427-5856

\section{Éditeur}

Rosenberg \& Sellier

\section{Édition imprimée}

Date de publication : 1 septembre 2011

Pagination : 449

ISSN : 0039-2944

\section{Référence électronique}

Ida Merello, «Bertrand Vibert, Poète, même en prose », Studi Francesi [En ligne], 164 (LV | II) | 2011, mis en ligne le 30 novembre 2015, consulté le 08 janvier 2021. URL : http://journals.openedition.org/ studifrancesi/5738 ; DOI : https://doi.org/ERREUR PDO dans /localdata/www-bin/Core/Core/Db/ Db.class.php L.34 : SQLSTATE[HY000] [2006] MySQL server has gone away

Ce document a été généré automatiquement le 8 janvier 2021.

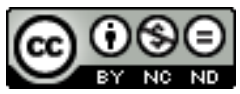

Studi Francesi è distribuita con Licenza Creative Commons Attribuzione - Non commerciale - Non opere derivate 4.0 Internazionale. 


\title{
Bertrand Vibert, Poète, même en prose
}

\author{
Ida Merello
}

\section{RÉFÉRENCE}

BERTRAND VIBERT, Poète, même en prose, Vincennes, Presses Universitaires de Vincennes, 2010, 419 pp.

1 L'A., dopo il primo volume della sua antologia dei Contes symbolistes, offre di essi ora un'analisi serrata, in prospettiva storica, attenta alle interferenze, alle filiazioni e all'evoluzione dei modelli, che per gli aspetti formali si appoggia invece alle categorie genettiane (le distinzioni di Fiction et diction, o le diverse modulazioni di un testo definite in Mimologies, o i valori dei «seuils»). Quello che preme all'A. è dimostrare la specificità del conte symboliste, distinto dal poème en prose per un carattere più spiccatamente narrativo, ma Symbaliste ugualmente poetico, dal momento che va a ricoprire quella zona che la poesia lirica, quasi incontrastata dal Romanticismo in poi, ha lasciato scoperta. Al di là della distinzione generica, l'A. intende dimostrare anche la qualità storica di questo tipo di contes, che si afferma essenzialmente tra gli anni 80 e 90 ed è caratterizzato da alcune costanti tematiche, oltre che da una forma musicale. Alle sue origini, l'A. mostra i riferimenti a Poe, a Baudelaire e, tra gli autori più prossimi, a Mallarmé e Villiers, che influenzano in vario modo personaggi come Bernard Lazare, Gourmont, Régnier, Rodenbach e, in misura minore, Schwob. All'indagine narratologica di impronta genettiana è attribuito il compito di definire formalmente le costanti di un genere di cui vengono isolati quindi gli elementi simbolici e i complessi mitici; mentre l'intratestualità permette di cogliere il progetto musicale. Il volume è corredato da un'ampia bibliografia. 


\section{AUTEURS}

IDA MERELLO

it 